\title{
Autologous TCR-engineered T-cells IMA201
}

National Cancer Institute

\section{Source}

National Cancer Institute. Autologous TCR-engineered T-cells IMA201. NCI Thesaurus.

Code $C 146779$.

A preparation of autologous T-lymphocytes that are genetically modified with a lentiviral vector encoding a T-cell receptor (TCR) specific for an as of yet not identified tumorassociated antigen (TAA), with potential antineoplastic activity. Upon intravenous administration back into the patient, the autologous T CR-engineered T-cells IMA201 specifically recognize and bind to the TAA on cancer cells, which induces a cytotoxic Tlymphocyte (CTL)-mediated immune response against the TAA-positive cancer cells. 